УДК 615.322:582.734

\title{
ВЫДЕЛЕНИЕ И АНАЛИЗ ЭКСТРАКТИВНЫХ ВЕЩЕСТВ ЛАПЧАТКИ БЕЛОЙ (РОTЕNTILLA ALBA L.), ВЫРАЩЕННОЙ В РАЗНЫХ УСЛОВИЯХ
}

\author{
() Н.Г. Базарнова, Л.И. Тихомирова, Н.С. Фролова, И.В. Микуиина"* \\ Алтайский государственный университет, пр. Ленина, 61, Барнаул, 656049 \\ (Россия), e-mail: mikuschinai@mail.ru
}

Potentilla alba L. (лапчатка белая) используется как лекарственное растение, содержащее разнообразные биологически активные вещества. Природные запасы не удовлетворяют потребности фармацевтической промышленности. Впервые получена биомасса растений-регенерантов $P$. alba в условиях гидропоники, сопряженной с клональным микроразмножением.

Проведено комплексное исследование химического состава лекарственного сырья $P$. alba, полученного в отделе биотехнологии (растений-регенерантов), в сравнении с выращенным в полевых условиях (интактных растений).

Установлено количественное содержание структурных компонентов в исследуемых образцах: целлюлозы в корнях и корневищах интактных растений $-15,4 \%$, в корнях растений-регенерантов - 4,3\%, в листьях растенийрегенерантов - 2,5\%; лигнина в корнях и корневищах интактных растений - 40,7\%, в корнях растений-регенерантов $37,0 \%$, в листьях растений-регенерантов $-36,8 \%$.

Определено содержание экстрактивных веществ в образцах $P$. alba, извлекаемых в результате последовательной обработки гексаном, $96 \%, 40 \%$ растворами этанола, водой и $1 \%$ водным раствором гидроксида натрия. Выявлено суммарное содержание экстрактивных веществ в корнях и корневищах интактных растений - 15,3\%, в корнях растений-регенерантов - $11,2 \%$, в листьях растений-регенерантов $-5,1 \%$.

Охарактеризован групповой химический состав экстрактивных веществ методом УФ-спектроскопии. В составе экстрактов доминирующими являются соединения фенольной природы с тах поглощения при $\lambda=279,5-280,0$ нм. Установлена подлинность исследуемых образцов $P$. alba методом ТCX-хроматографии по наличию флавоноидов и танинов. Показана идентичность фитохимического состава растительного сырья, получаемого, методом клонального микроразмножения и выращенного в условиях гидропоники в течение двух месяцев.

Ключевые слова: лекарственное растительное сырье, лапчатка белая, Potentilla alba L., интактные растения, pacтения-регенеранты, экстрактивные вещества, химический состав, флавоноиды, ТСХ-хроматография, УФспектроскопия.

\section{Введение}

Potentilla alba L. (лапчатка белая) вошла в официальную медицину более 30 лет назад [1]. Известно, что растение P. alba содержит углеводы (крахмал), иридоиды, сапонины, фенолкарбоновые кислоты, флавоноиды, дубильные вещества [2-4]. Лекарственные средства на основе $P$. alba оказывают влияние на щитовидную железу $[5,6]$. Несмотря на то, что растение наиболее широко применяется при лечении гиперфункции железы (тиреотоксикозе), отмечен положительный эффект и при лечении гипофункции [7, 8]. Именно тиреотропной активностью корней $P$. alba исследователи объясняют тот факт, что в Белорусском

Базарнова Наталья Григорьевна - заведующая кафедрой органической химии, декан химического факультета, доктор химических наук, профессор, e-mail: bazarnova@chemwood.asu.ru

Тихомирова Людмила Ивановна - кандидат биологических наук, заведующая отделом биотехнологии растений ЮСБС АлтГУ Фролова Наталья Сергеевна - магистр Микушина Ирина Владимировна - доцент кафедры органической химии, кандидат химических наук, e-mail: mikuschinai@mail.ru
Полесье, где распространена практика употребления лапчатки в виде отвара вместо чая, после аварии на Чернобыльской АЭС было зафиксировано крайне мало случаев заболевания эндемическим зобом по сравнению с другими районами, прилегающими к месту трагедии [3]. Кроме того, фитотерапевты рекомендуют применять $P$. alba при профилактике и терапии заболеваний печени, сердечно-сосудистой

\footnotetext{
"Данная статья имеет электронный дополнительный материал (приложение), который доступен читателям на сайте журнала. DOI: 10.14258/jcprm.201601933s

Автор, с которым следует вести переписку.
} 
системы и желудочно-кишечного тракта, а также как антисептическое и ранозаживляющее средство [9]. Несмотря на обширный ареал, природные запасы лапчатки достаточно скудны и не могут удовлетворить современных потребностей фармацевтической промышленности [10].

Учеными Алтайского государственного университета разработан способ получения лекарственного растительного сырья $P$. alba в условиях гидропоники, сопряженной с клональным микроразмножением [11, 12].

Целью данного исследования являлась сравнительная фитохимическая характеристика биомассы растительного сырья $P$. alba, выращенного в полевых условиях и в условиях гидропоники, сопряженной с микроклональным размножением.

\section{Экспериментальная часть}

В качестве объекта исследования использовали образцы корней и корневищ $P$. alba интактных растений, выращенных и используемых в производстве ЗАО «Эвалар (Бийск, Россия), а также корней и листьев растений-регенерантов, выращенных в гидропонных условиях, сопряженных с микроклональным размножением, в отделе биотехнологии растений Алтайский государственный университет (Барнаул, Россия).

Сушка и измельчение растительного сырья. Перед сушкой растительное сырье сортировали и очищали от инородных примесей и сгнивших частей.

Для сушки растительное сырье, в соответствии с рекомендациями [13], сразу же после сбора рассыпали тонким слоем. Хорошо высушенное лекарственное сырье должно содержать не более 12-15\% гигроскопической влаги.

Воздушно-сухие образцы листьев и корней, корневищ $P$. alba перемалывали на ручной кофемолке до размера частиц 2-4 мм.

Подготовленные таким образом образцы анализировали на содержание влаги, золы, целлюлозы и лигнина по стандартным методикам [14].

Экстрагирование растительного сырья. За основу фитохимического исследования была принята схема, описанная В.М. Косман с коллегами [15]. Согласно этой схеме экстрактивные вещества извлекали из растительного сырья путем последовательной обработки образцов различными растворителями: гексаном, этиловым спиртом нисходящей концентрации (96 и 40\%), водой и 1\% раствором гидроксида натрия. Экстракцию гексаном и спиртовыми растворами проводили в аппарате Сокслета обработкой образцов в соотношении сырье - экстрагент $1: 50$. Обработку водой и $1 \%$ раствором щелочи проводили выдерживанием образцов в растворе при температуре $50-70{ }^{\circ} \mathrm{C}$, при соотношении сырье - экстрагент $1: 50$.

Содержание экстрактивных веществ, извлекаемых различными по природе растворителями, из одного и того же образца при последовательной обработке определяли количественно после отгонки растворителя, расчет производили с учетом влажности получаемого после удаления растворителя сухого экстракта.

Идентификация основных биологически активных компонентов лапчатки белой выполнена в соответствии с общепринятыми методиками [16]. Флавоноиды идентифицировали по качественной цианидиновой реакции (восстановление цинковой пылью в кислой среде). Флавоноиды при восстановлении в присутствии концентрированной хлористоводородной кислоты дают красное окрашивание.

Полисахариды, взаимодействуя со щелочью, окрашиваются в желтый цвет.

Черно-зеленое окрашивание наблюдалось при взаимодействии дубильных веществ экстрактов с солями железа.

Полифенольные соединения в экстракте с сульфатом закисного железа дают темно-синее окрашивание даже после реакции осаждения ацетатом свинца.

Антоцианидины в кислой среде сразу образовывают окрашенные оксониевые соли. Проба Брианта позволяет обнаруживать в экстрактах агликоны и (или) гликозиды.

Характеризащию группового химического состава экстрактов осуществляли методом УФспектроскопии по оптическим плотностям различных растворов на UV-Vis Cary 60. (Agilent Technologies, USA) в области спектра 210-600 нм.

Установление подлинности исследуемых образиов Р. alba по наличию флавоноидов проводили методом ТCX-хроматографии по методикам, реализуемым на фармацевтических производствах [17].

Элюирование анализируемой смеси проводили восходящим способом смесью растворителей. Неподвижной фазой являлся силикагель на алюминиевой подложке. Исследуемое вещество наносили в количестве 30 мкл на линию старта пластины и осуществляли элюирование смесью растворителей этилацетат - метанол 
- вода - муравьиная кислота (50:2 : $3: 6$ по объему соответственно). Хроматограмму проявляли с помощью раствора дифенилборной кислоты аминоэтилового эфира и макрогола 400, затем просматривали в УФ-свете.

Установление подлинности исследуемых образцов P. alba по наличию танинов. Танины из исследуемых образцов извлекали водой и этилацетатом, экстракты объединяли и фильтровали через безводный сульфат натрия, упаривали до сухого остатка и растворяли в 2 мл этилацетата, анализировали методом ТСХ, используя метод сравнения со свидетелем (раствор 1,0 мг катехина в 1,0 мл метанола), проявляли свежеприготовленным 5 г/л раствором красителя fast blue $\mathrm{B}$ salt $\mathrm{R}$ (3,3'-диметоксибифенил-4,4'бис(диазоний) гексахлорцинкат) при в дневном свете.

Все измерения проведены не менее чем в трехкратной повторности. Все расчеты по содержанию различных веществ приведены на абсолютно сухую массу.

\section{Обсуждение результатов}

В отделе биотехнологии растений Южно-Сибирского ботанического сада Алтайского государственного университета (АлтГУ) впервые получена биомасса растений-регенерантов $P$. alba в условиях гидропоники, сопряженной с клональным микроразмножением. На кафедре органической химии химического факультета АлтГУ проведено комплексное исследование химического состава лекарственного сырья $P$. alba (интактных растений), выращенного в полевых условиях и используемого в производстве ЗАО «Эвалар» (Бийск, Россия), а также сырья, полученного альтернативным способом в отделе биотехнологии (растений-регенерантов).

Воздушно-сухие образцы надземной биомассы, корней и корневищ $P$. alba анализировали на содержание золы, влаги и высокомолекулярных компонентов (табл. 1).

Полученные значения влажности находятся в допустимых пределах, так как для большинства видов лекарственного растительного сырья максимальная влажность обычно составляет не более 12-15\%. Влажность корней растений-регенерантов и интактных растений мало различается, в то время как листья растений-регенерантов характеризуются более низким значением влажности, что связано с особенностями морфологического строения различных частей растений.

Наличие макро- и микроэлементов в лекарственном растительном сырье характеризует его качество. Присутствие и накопление минеральных веществ зависит от почв и условий выращивания лекарственных растений и определяется количеством золы. Количество золы в лекарственном сырье обычно колеблется в широких пределах и зависит от многих факторов, в том числе от способа сбора и условий сушки. Как показано авторами [15], содержание общей золы в корнях и корневищах трехлетних образцов $P$. alba выше $(5,8 \%)$, чем четырехлетних $(5,0 \%)$. Образцы интактных растений, изучаемые нами, мало отличаются по содержанию золы от описанных в литературе. Образцы $P$. Alba, полученные с использованием метода клонального микроразмножения, существенно различаются по содержанию золообразующих веществ. Также нами установлено, что отдельные части образцов $P$. alba, выращенных в условиях клонального микроразмножения, различаются по содержанию золы. Автор [18] указывает на то, что в подземной части растений обнаруживают больше минеральных веществ, чем в надземной, кроме того, накопление некоторых минеральных веществ связано с периодами вегетации и максимально в фазу цветения. Таким образом, низкие значения содержания зольных веществ в образцах растений-регенерантов связаны с незначительным возрастом этих растений (2 месяца) и вегетативным развитием до цветения.

Интересным представляется соотношение высокомолекулярных компонентов в сравниваемом растительном сырье. Так, содержание целлюлозы в корнях и корневищах интактных растений составляет $15,4 \%$, в корнях растений-регенерантов значительно ниже - 4,3\%. Небольшое содержание целлюлозы в растениях-регенерантах, вероятно, связано с тем, что их возраст всего 2 месяца, а интактных растений приблизительно 4 года. Поэтому биомасса молодых растений до заготовки растительного сырья состояла из большего количества живых тканей (паренхимных клеток с тонкой первичной стенкой, в которых активно происходили сложные химические процессы и обмен веществ), а с увеличением возраста растения происходит накопление прозенхимных клеток, которые содержат прежде всего целлюлозное волокно. Содержание целлюлозы в листьях растений-регенерантов еще ниже - 2,5\%, так как зеленые части растений осуществляют различные функции живых растений и имеют весьма разнообразный состав веществ и низкое содержание высокомолекулярных полисахаридов. Содержание лигнина (как сумма веществ конденсированных фенольных соединений) в образцах отличается незначительно: в корнях и корневищах интактных растений оно составляет 40,7\%, в корнях и листьях растений-регенерантов - 37,0 и 36,8\% соответственно, что, скорее всего, свидетельствует о завершении процесса биосинтеза лигнина. 
Таблица 1. Макрокомпоненный состав P. alba (в пересчете на а.с.в.), \%

\begin{tabular}{l|c|c|c|c}
\hline \multicolumn{1}{c|}{ Исходное сырье } & Зольность & Влажность & Целлюлоза & Лигнин \\
\hline Корни и корневища (интактные растения) & $5,1 \pm 0,2$ & $8,5 \pm 0,1$ & $15,4 \pm 0,4$ & $40,7 \pm 0,3$ \\
Корни (растения-регенеранты) & $3,2 \pm 0,1$ & $8,1 \pm 0,1$ & $4,3 \pm 0,2$ & $37,0 \pm 0,3$ \\
Листья (растения-регенеранты) & $2,3 \pm 0,1$ & $5,1 \pm 0,2$ & $2,5 \pm 0,3$ & $36,8 \pm 0,1$ \\
\hline
\end{tabular}

ИК-спектроскопический анализ лигнинов, выделенных из исследуемых образцов растительного сырья (рис. 1), демонстрирует идентичность их структуры.

Лигнин на ранних стадиях образуется в сформировавшихся растительных клетках. У некоторых растений на 2-3-й день клеточные стенки начинают давать качественную реакцию на лигнин - красное окрашивание солянокислым раствором флороглюцина. Независимо от способа выращивания растений $P$. alba, структура лигнинов клеточной стенки остается неизменной и является наследственно закрепленным признаком.

Наиболее важными компонентами растительного сырья являются экстрактивные вещества, извлекаемые различными растворителями. По данным [18] содержание экстрактивных веществ в лапчатке максимально может достигать $17 \%$ в подземной части (в фазу цветения), $6 \%$ в надземной части растения.

Количественное содержание экстрактивных веществ (в виде сухого экстракта, получаемого после удаления растворителя), извлекаемых различными по природе растворителями из одного и того же образца при последовательной обработке, приведено в таблице 2.

В результате последовательной непрерывной обработки образцов растворителями достигается более полное извлечение экстрактивных веществ. Суммарное содержание экстрактивных веществ в корнях и корневищах интактных растений составляет $15,3 \%$, в корнях растений-регенерантов - 11,2\%, в листьях растений-регенерантов - 5,1\%, что не противоречит известным данным [18].

Содержание экстрактивных веществ, извлеченных гексаном (липиды), минимально и составляет от 0,3 до $1,7 \%$, экстракт окрашен в светло-желтый цвет.

Наибольшее количество экстрактивных веществ (выход от 2,5 до 5,6\%) извлечено 96\% этанолом.

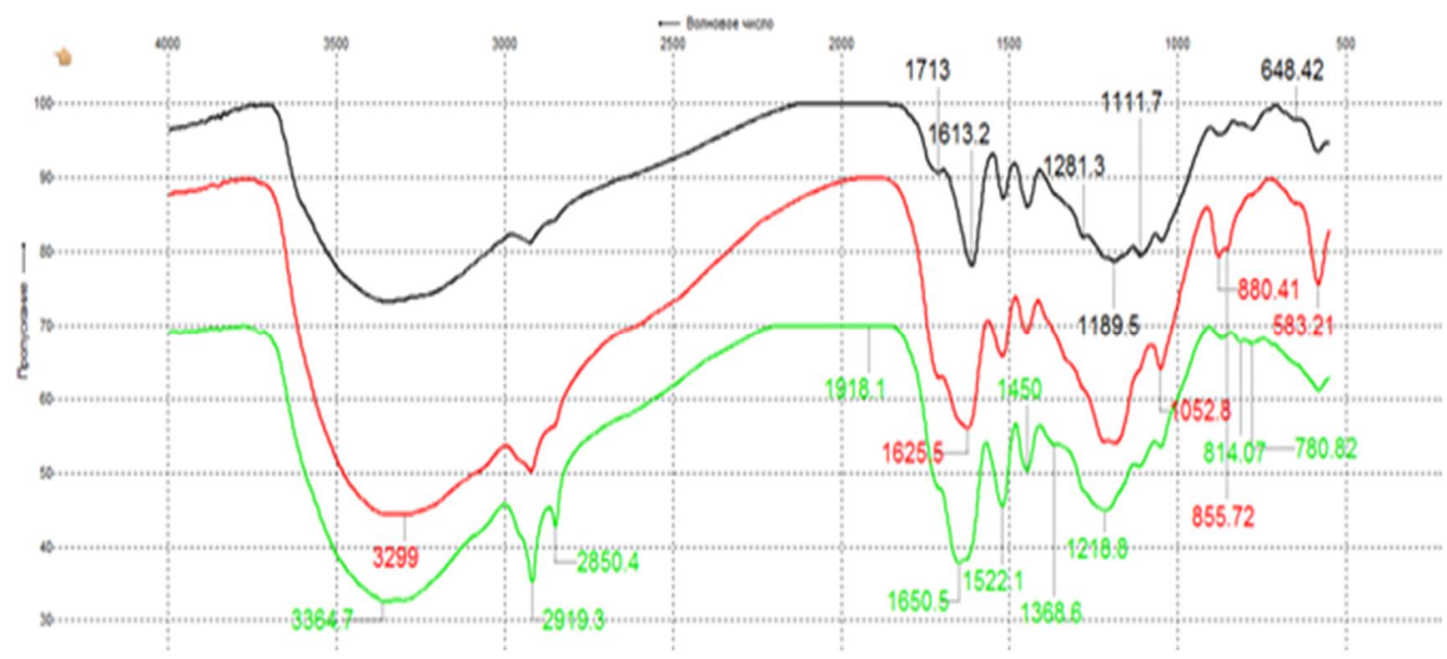

Рис. 1. ИК-спектры лигнина P. alba: 1 - корней и корневищ интактных растении; 2 - корней растенийрегенерантов; 3 - листьев растений-регенерантов

Таблица 2. Содержание экстрактивных веществ $P$. alba при последовательной экстракции (в пересчете на a.c.в.), \%

\begin{tabular}{l|c|c|c}
\hline \multicolumn{1}{c|}{ Растворитель } & $\begin{array}{c}\text { В корнях и корневищах } \\
\text { интактных растений }\end{array}$ & $\begin{array}{c}\text { В корнях растений- } \\
\text { регенерантов }\end{array}$ & $\begin{array}{c}\text { В листьях растений- } \\
\text { регенерантов }\end{array}$ \\
\hline Гексан & $1,7 \pm 0,1$ & $0,9 \pm 0,1$ & $0,3 \pm 0,2$ \\
$96 \%$ раствор этанола & $5,6 \pm 0,2$ & $4,4 \pm 0,4$ & $2,5 \pm 0,2$ \\
$40 \%$ раствор этанола & $5,2 \pm 0,2$ & $4,2 \pm 0,2$ & $1,7 \pm 0,3$ \\
Вода & $1,9 \pm 0,3$ & $1,0 \pm 0,2$ & $0,3 \pm 0,2$ \\
$1 \%$ раствор $\mathrm{NaOH}$ & $0,9 \pm 0,2$ & $0,7 \pm 0,1$ & $0,3 \pm 0,1$ \\
Общее содержание & 15,3 & 11,2 & 5,1 \\
\hline
\end{tabular}


Содержание экстрактивных веществ, извлеченных 40\% этанолом, составляет от 1,7 до 5,2\%. Спиртовые экстракты имеют темно-желтую окраску в корнях и корневищах и зеленую в листьях. Этанолом извлекаются полифенольные соединения, фенольные кислоты, флавоноиды, антоцианидины.

Содержание экстрактивных веществ, извлеченных водой (полисахариды, аминокислоты и дубильные вещества), составляет от 0,3 до 1,9\%, цвет экстрактов темно-коричневый.

Содержание экстрактивных веществ, извлеченных 1\% раствором $\mathrm{NaOH}$ (дубильные вещества), составляет от 0,3 до $0,9 \%$, цвет экстрактов темно-бордовый [15].

Несмотря на более низкое суммарное содержание экстрактивных веществ в корнях и листьях растений-регенерантов, соотношение различных групп веществ в экстрактах незначительно отличается от такового для интактных растений (рис. 2).

В экстрактах из образцов растений-регенерантов содержится несколько меньше веществ, растворимых в гексане (липидов) и воде (аминокислот и полисахаридов). В $1 \%$ водном растворе $\mathrm{NaOH}$ растворяется сопоставимое количество веществ (дубильных веществ). Это связано с уменьшением количества проводящих тканей во флоэме 4-летних интактных растений и увеличением биомассы запасающих клеток, которые накапливают липиды, аминокислоты и дубильные вещества. В то же время экстракты из корней растений-регенерантов содержат больше веществ, растворимых в 96 и 40\% этаноле (полифенольные соединения, флавоноиды, антоцианы). Экстракты из листьев растений-регенерантов превосходят по содержанию веществ, растворимых в 96\% этаноле (полифенольные соединения), все другие образцы. Авторами [19] отмечено увеличение общей суммы фенольных соединений в каллусах по сравнению с интактными растениями и неравномерное их распределение в каллусах листового и корневого происхождения. Таким образом, экстракты из растений-регенерантов в незначительно большей степени обогащены биологически активными веществами фенольной природы.

В экстрактах качественно идентифицированы основные группы биологически активных веществ (табл. 3).

С помощью качественных реакций во всех исследуемых образцах растительного сырья P.alba, независимо от способа получения, обнаружены флавоноиды, полисахариды, дубильные вещества, антоцианидины, гликозиды и агликоны. Установлена идентичность группового состава биологически активных веществ интактных растений и растений-регенерантов.

Методом УФ-спектроскопии анализировали экстрактивные вещества, извлеченные из корней и корневищ $P$. alba интактных растений, корней растений-регенерантов и листьев растений-регенерантов различными растворителями: 96 и 40\% водными растворами этанола, водой и $1 \%$ раствором $\mathrm{NaOH}$ (табл. 4). В состав экстрактов листьев, корней и корневищ $P$. alba входят преимущественно флавононы и флавононолы [20], что подтверждается положением полосы в области 275-280 нм, отсутствует полоса при больших длинах волн в УФ-спектрах (см. электронное приложение, рис. 1).

Из анализа спектров следует, что водные и водно-спиртовые экстракты содержат вещества сходной природы с максимумами поглощения в области 280 нм, что характерно для соединений фенольной природы (флавоноиды) [20].

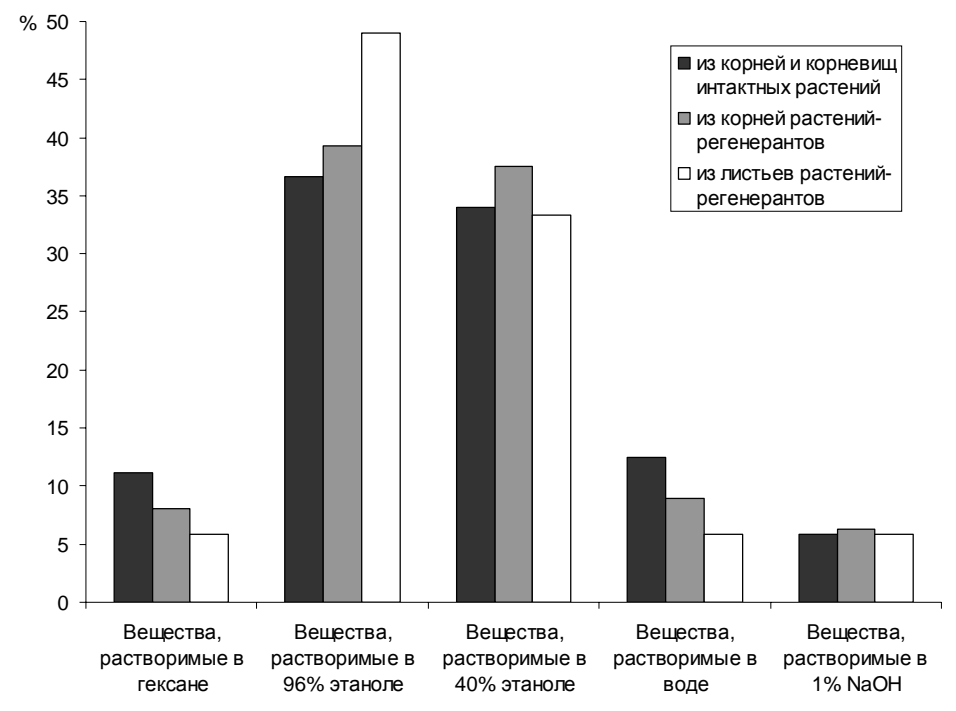

Рис. 2. Накопление основных групп биологически активных веществ в интактных растениях и растениях-регенерантах 
В работе [21] описан УФ-спектр апигенина, входящего в состав флавоноидов P. alba (рис. 3А). По положению максимума данного спектра авторы предлагают стандартизировать лекарственное сырье на предмет содержания флавоноидов. УФ-спектр водно-спиртового (40\%) экстракта из корней растенийрегенерантов $P$. alba (рис. 3Б) идентичен по положению максимума, описанному в литературе. Таким образом, можно утверждать, что растения-регенеранты даже при незначительных сроках интродукции (2 месяца) содержат в своем составе биологически активные вещества из группы флавоноидов.

Таблица 3. Характеристика группового состава P.alba

\begin{tabular}{l|c|c|c}
\hline \multicolumn{1}{c|}{ Группа веществ } & $\begin{array}{c}\text { В корнях и корневищах } \\
\text { интактных растений }\end{array}$ & $\begin{array}{c}\text { В корнях растений- } \\
\text { регенерантов }\end{array}$ & $\begin{array}{c}\text { В листьях растений- } \\
\text { регенерантов }\end{array}$ \\
\hline Флавоноиды (флавоны, флавонолы и & + & + & + \\
флавононы) - цианидиновая проба & + & + & + \\
Полисахариды & + & + & + \\
Дубильные вещества & + & + & + \\
Полифенольные соединения & + & + & + \\
Антоцианидины & + & + & + \\
Гликозиды & + & + & + \\
Агликоны & + & & + \\
\hline
\end{tabular}

Таблица 4. Полосы поглощения в УФ-спектрах биологически активных веществ P.alba

\begin{tabular}{|c|c|c|}
\hline Экстрагент & Образец & Мах поглощения \\
\hline $\begin{array}{l}96 \% \text { водный } \\
\text { раствор этанола }\end{array}$ & $\begin{array}{l}\text { корни и корневища интактных растений } \\
\text { корни растений-регенерантов } \\
\text { листья растений-регенерантов }\end{array}$ & $\begin{array}{c}279,5 \text { нм, слабо выражен, неинтенсивный } \\
279,5 \text { нм, слабо выражен, неинтенсивный } \\
\text { Отсутствует }\end{array}$ \\
\hline $\begin{array}{l}\text { 40\% водный } \\
\text { раствор этанола }\end{array}$ & $\begin{array}{l}\text { корни и корневища интактных растений } \\
\text { корни растений-регенерантов } \\
\text { листья растений-регенерантов }\end{array}$ & $\begin{array}{l}280,0 \text { нм, явно выражен, интенсивный } \\
280,0 \text { нм, явно выражен, интенсивный } \\
280,0 \text { нм, явно выражен, интенсивный }\end{array}$ \\
\hline Вода & $\begin{array}{l}\text { корни и корневища интактных растений } \\
\text { корни растений-регенерантов } \\
\text { листья растений-регенерантов }\end{array}$ & $\begin{array}{c}280,0 \text { нм, слабо выражен, неинтенсивный (в виде плеча) } \\
277,5 \text { нм, явно выражен, интенсивный } \\
279,5 \text { нм, слабо выражен, неинтенсивный }\end{array}$ \\
\hline $\begin{array}{l}1 \% \text { раствор } \\
\mathrm{NaOH}\end{array}$ & $\begin{array}{l}\text { корни и корневища интактных растений } \\
\text { корни растений-регенерантов } \\
\text { листья растений-регенерантов }\end{array}$ & $\begin{array}{l}279,5 \text { нм, слабо выражен, неинтенсивный (в виде плеча) } \\
280,0 \text { нм, слабо выражен, неинтенсивный (в виде плеча) } \\
280,0 \text { нм, слабо выражен, неинтенсивный (в виде плеча) }\end{array}$ \\
\hline
\end{tabular}

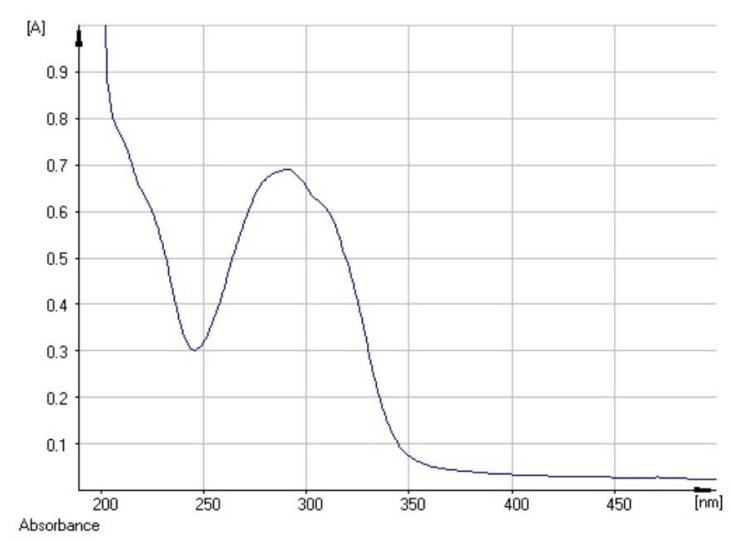

A

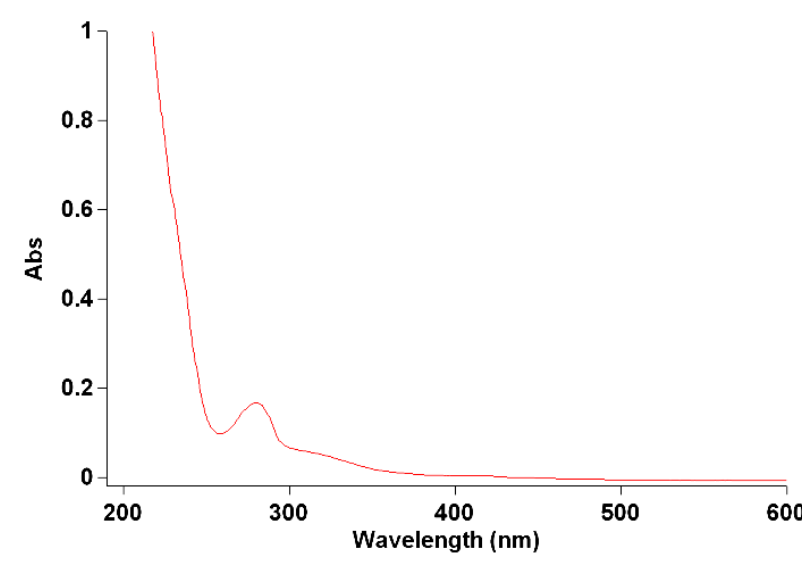

Б

Рис. 3. УФ-спектры апигенина (А) по данным [21] и водно-спиртовых экстрактов из корней растенийрегенератнов P. alba (Б)

\section{Установление подлинности исследуемых образцов Р. alba}

Флавоноиды являются основными компонентами, обладающими терапевтической активностью. Они не токсичны для человека при любом способе введения. Многие флавоноиды обладают Р-витаминной активностью, уменьшают хрупкость кровеносных капилляров (рутин), усиливают действие аскорбиновой кислоты, оказывают седативное действие. Данная группа веществ привлекает внимание ученых разносторонней биологической активностью и чрезвычайно низкой токсичностью. В последние годы появились сообщения о 
противоопухолевом действии флавоноидов. Поэтому одной из важных задач в производстве лекарственных препаратов является установление подлинности на присутствие флавоноидов в лекарственном сырье.

В последнее время для обнаружения флавоноидов широко используется хроматография на бумаге и в тонком слое сорбента. Установление подлинности исследуемых образцов $P$. alba проводили методом TCX-хроматографии по методикам, реализуемым на фармацевтических производствах.

Результаты ТСХ (см. электронное приложение рис. 2) свидетельствуют о том, что в экстрактах, полученных из корней и корневищ интактных растений, корней и листьев растений-регенерантов с использованием 96\%-ного раствора этанола, содержится 4 одинаковых группы веществ с Rf равными 0,58, что соответствует цинарозиду, 0,61 - рутину, 0,93 - апигенину, 0,97 - кверцетину.

Корни растений-регенерантов содержат флавоноиды идентичные по составу флавоноидам корней и корневищ интактных растений. На основании результатов ТСХ, показано, что и в листьях растенийрегенерантов содержится идентичный корням и корневищам состав флавоноидов. Аналогичные результаты были получены автором [18] при изучении надземной части $P$. alba, культивируемой на территории ЦБС НАН Белоруси. Надземная часть (листья) $P$. alba так же может быть использована в производстве лекарственных препаратов, так как содержит аналогичные группы биологически активных веществ.

Таким образом, подтверждена подлинность исследуемых образцов $P$. alba методом TCXхроматографии: образцы биомассы $P$. alba, выращенной методом клонального микроразмножения, соответствуют образцу биомассы $P$. alba, выращенной в естественных условиях по качественному составу.

Танины - группа фенольных соединений растительного происхождения, содержащих большое количество групп - ОН. В медицине танины находят применение как вяжущие лекарственные средства, противоядия (при отравлении солями свинца, ртути и др.), противодиарейные, кровоостанавливающие и противогеморроидальные средства, поэтому их присутствие обязательно в лекарственном сырье. С этой целью одной из обязательных процедур является установление подлинности на танины.

Танины из исследуемых образцов извлекали водой и этилацетатом, а затем анализировали методом TCX (см. электронное приложение рис. 3).

В растениях-регенерантах и в корнях, и в листьях присутствуют танины в незначительном количестве, по сравнению со стандартом и интактными растениями

\section{Выводы}

Проведен анализ макрокомпонентного состава и экстрактивных веществ $P$. alba интактных растений (срок интродукции 4 года) и растений-регенерантов, полученных методом клонального микроразмножения и выращенных в условиях гидропоники Отдела биотехнологии растений Алтайского государственного университета (срок интродукции 2 месяца). Исследуемые образцы растений-регенерантов содержат в своем составе все группы биологически активных веществ, характерных для данного вида растительного сырья. Показано, что соотношение групп БАВ в экстрактах исследуемых образцов отличаются незначительно, причем в экстрактах растений-регенерантов найдено несколько больше веществ растворимых в $96 \%$ и $40 \%$ этаноле. Методом УФ-спектроскопии установлено наличие флавоноидов, а методом ТСХ обнаружены цинарозид, рутин, апигенин, кверцетин в этанольных экстрактах из корней и корневищ интактных растений, корней и листьев растений-регенерантов. Таким образом, показана идентичность фитохимического состава растительного сырья получаемого, методом клонального микроразмножения и выращенного в условиях гидропоники в течение 2 месяцев.

Дальнейшее изучение количественного соотношения отдельных биологически активных веществ в экстрактах растений-регенерантов позволит оценить перспективы использования данного вида лекарственного растительного сырья как одного из важнейших источников получения лекарственных и профилактических средств современной медицины.

Коллектив авторов выражает благодарность Харлампович Татьяне Анатольевне, канд. фарм наук, 3АО «Эвалар» за консультации и содействие при установлении подлинности растительного сырья P. alba.

\section{Список литературы}

1. Китаева М.В. Введение в культуру in vitro редких лекарственных растений Potentilla L. Интродукция, сохранение и использование биологического разнообразия мировой флоры // Материалы Международной конференции, посвященной 80-летию Центрального ботанического сада Национальной академии наук Беларуси. Минск, 2012. С. 398-401. 
2. Гриценко О.М., Смык Г.К. Фитохимические исследования лапчатки белой // Фармацевтический журнал. 1977. №1. С. $88-92$

3. Лавренов В.К., Лавренова Г.К. Полная энциклопедия лекарственных растений. СПб. ; М., 1999. Т. 1. 736 с.

4. Семёнова Е.Ф., Преснякова Е.В. Химический состав лапчатки белой и применение ее с лечебной целью // Химия и компьютерное моделирование. Бутлеровские сообщения. 2001. №5. [Электронный ресурс]. URL: http://chem.kstu.ru/butlerov_comm/vol2/cd-a2/data/jchem\&cs/russian/n5/1vr103/103.htm

5. Захария А.В. Исследование лапчатки белой как перспективного средства для лечения заболеваний щитовидной железы : автореф. дис... канд. биол. наук. Львов, 1997. 24 с.

6. Архипова Э.В. Влияние экстракта Potentilla alba L. и комплексного средства «Тиреотон» на течение экспериментального гипотиреоза: автореф. дис. ... канд. мед. наук. Улан-Удэ, 2012. 21 с.

7. Смик Г.К., Кривенко В.В. Перстач білий - ефективный засиб для ликування захворювань щитовидної залози // Фармацевтичний журнал. 1975. №2. С. 58-62.

8. Приходько Е.И. Лечение больных тиреотоксикозом травой пестрач белый // Врачебное дело. 1976. №6. С. 6671.

9. Шимко О.М., Хишова О.М. Оценка травы лапчатки белой // Вестник фармации 2010. №1(47). С. 17-24.

10. Смык Г.К. Использование лапчатки белой как нового лекарственного растения, восстановление запасов ее в природе и возможности культуры // Новые культуры в народном хозяйстве и медицине: в 2 ч. 1976. Ч. 1. C. $41-42$.

11. Патент № 2525676 (РФ). Способ получения лапчатки белой (Potentilla alba L.) / Л.И. Тихомирова, В.Н. Буркова / 2012.

12. Патент № 2570623 (РФ). Способ получения лекарственного растительного сырья лапчатки белой (Рotentilla alba L) в условиях гидропоники / Н.Г. Базарнова, Л.И. Тихомирова / 2015.

13. Башилов А. В. Использование Potentilla alba L. в качестве лекарственного растительного сырья в условиях республики Беларусь // Экологический вестник. 2010. №3. С. 85-88.

14. Оболенская А.В. Лабораторные работы по химии древесины и целлюлозы. М., 1991. 320 с.

15. Косман В.М., Фаустова Н.М., Пожарицкая О.Н., Шиков А.Н., Макаров В.Г. Накопление биологически активных веществ в подземных частях лапчатки белой (Potentilla alba L.) в зависимости от срока культивирования // Химия растительного сырья. 2013. №2. С. 139-146.

16. Ботиров Э.Х., Дренин А.А., Макарова А.В. Химическое исследование флавоноидов лекарственных и пищевых растений // Химия растительного сырья. 2006. №1. С. 45-48.

17. Зайчикова С.Г., Самылина И.А. Новожилова Т.И. Изучение липидного и флавоноидного состава образцов некоторых видов рода чины (Lathyrus) // Химико-фармацевтический журнал. 2001. Т. 35. №5. С. 36-38.

18. Башилов А.В. К вопросу о фармаколого-биохимическом обосновании практического использования Potentila alba // Известия национальной академии наук Белоруссии. Серия биологических наук. 2012. №1. С. 119-123.

19. Китаева М.В., Зубарев А.В., Спиридович Е.В., Решетников В.Н. Вторичные метаболиты фенольной природы Potentila alba L. в условиях in vitro // Труды БГУ. Биохимия. 2011. Т. 6, №1. С. 123-127.

20. Куркина А.В., Осипова А.А. Новые подходы к стандартизации сырья эрвы шерстистой // Химия растительного сырья. 2010. №2. С. 117-121.

21. Хусаинова А.И., Куркина А.В. Оптимизация подходов к стандартизации сырья пижмы обыкновенной в рамках ресурсосберегающих технологий // Известия Самарского научного центра Российской академии наук. 2013. T. 15. №3(6). C. 1984-1987.

Поступило в редакиию 8 декабря 2015 г. 
Bazarnova N.G., Tikhomirova L.I., Frolova N.S., Mikushina I.V.* ISOLATION AND ANALYSIS OF EXTRACTIVES POTENTILLA ALBA (POTENTILLA ALBA L.), GROWN UNDER DIFFERENT CONDITIONS

Altai State University, pr. Lenina, 61, Barnaul, 656049 (Russia), e-mail: mikuschinai@mail.ru

Potentilla alba $L$. is used as a medicinal plant that contains a variety of biologically active substances. Natural resources are not meeting the needs of the pharmaceutical industry. We got the first biomass plant regenerated $P$. alba in a hydroponic with micropropagation.

We have conducted a comprehensive study of the chemical composition of a vegetable raw materials $P$. alba, prepared in the Department of Biotechnology (plants-regenerants) compared with those grown under field conditions (intact plants).

We have established the quantitative content of the structural components in the samples: cellulose in roots and rhizomes of intact plants $-15,4 \%$, in the roots of the plants regenerated $-4,3 \%$, in the leaves of regenerated plants $-2,5 \%$; lignin in roots and rhizomes of intact plants $-40,7 \%$, in the roots of regenerated plants $-37,0 \%$, in the leaves of regenerated plants $36,8 \%$.

We determined the content of extractives in samples $P$. alba, recovered by sequential treatment with hexane, $96 \%$ and $40 \%$ ethanol solution, water and $1 \%$ aqueous sodium hydroxide solution. We identified a total content of extractives in the roots and rhizomes of intact plants $-15,3 \%$, in the roots of regenerated plants $-11,2 \%$, in the leaves of regenerated plants $-5,1 \%$.

We have characterized the chemical composition of extractives by UV-spectroscopy. Phenolic compounds $(\lambda=279,5$ $280,0 \mathrm{~nm}$ ) are dominant in the composition of the extracts. We have established the authenticity of the samples by the TLC chromatography by the presence of flavonoids and tannins. We showed the identity of the phytochemical composition of vegetable raw materials produced by micropropagation and grown in a hydroponics for 2 months.

Keywords: medicinal herbs, bloodroot white, Potentilla alba L.,intact plants, regenerated plants, extractive substances, chemical composition, flavonoids, TLC-chromatography, UV-spectroscopy.

\section{References}

1. Kitaeva M.V. Materialy Mezhdunarodnoj konferencii, posvjashhennoj 80-letiju Central'nogo botanicheskogo sada Nacional'noj akademii nauk Belarusi. [Proceedings of the International Conference on the 80th anniversary of the Central Botanical Garden of the National Academy of Sciences]. Minsk, 2012, pp. 398-401. (in Russ.).

2. Gricenko O.M., Smyk G.K. Farmacevticheskij zhurnal, 1977, no. 1, pp. 88-92. (in Russ.).

3. Lavrenov V.K., Lavrenova G.K. Polnaja Jenciklopedija lekarstvennyh rastenij. [Complete Encyclopedia of medicinal plants]. Saint Petersburg; Moscow, 1999, vol. 1, 736 p. (in Russ.).

4. Semjonova, E.F., Presnjakova, E.V. Himija i komp'juternoe modelirovanie. Butlerovskie soobshhenija. 2001, no. 5. URL: http://chem.kstu.ru/butlerov_comm/vol2/cd-a2/data/jchem\&cs/russian/n5/1vr103/103.htm (in Russ.).

5. Zaharija A.V. Issledovanie lapchatki beloj, kak perspektivnogo sredstva dlja lechenija zabolevanij shhitovid-noj zhelezy: avtoref. dis... kand. biol. nauk. [Research cinquefoil white as a promising agent for the treatment of thyroid diseases: Author. Dis ... candidate of biological sciences.]. L'vov, 1997, 24 p. (in Russ.).

6. Arhipova Je.V. Vlijanie jekstrakta Potentilla alba L. $i$ kompleksnogo sredstva «Tireoton» na techenie jeksperimental'nogo gipotireoza: avtoref. dis. ... kand. med. nauk. [Effect of extract of Potentilla alba L. and integrated means "Tireotom" on the course of experimental hypothyroidism: Author. Dis. ... Candidate of Medical Sciences]. UlanUdje, 2012, 21 p. (in Russ.).

7. Smik G.K., Krivenko V.V. Farmacevtichnij zhurnal. 1975, no. 2, pp. 58-62. (in Russ.).

8. Prihod'ko E.I. Vrachebnoe delo, 1976, no. 6, pp. 66-71. (in Russ.).

9. Shimko O.M., Hishova O.M. Vestnik farmacii, 2010, no. 1(47), pp. 17-24. (in Russ.).

10. Smyk G.K. Novye kul'tury v narodnom hozjajstve i medicine. 1976, vol. 1, pp. 41-42. (in Russ.).

11. Patent 2525676 (RU). 2012. (in Russ.).

12. Patent 2570623 (RU). 2015. (in Russ.).

13. Bashilov A.V. Jekologicheskij vestnik, 2010, no. 3, pp. 85-88. (in Russ.).

14. Obolenskaja A.V. Laboratornye raboty po himii drevesiny i celljulozy. [Laboratory work on the chemistry of wood and cellulose]. Moscow, 1991, 320 p. (in Russ.).

15. Kosman V.M., Faustova N.M., Pozharickaja O.N., Shikov A.N., Makarov V.G. Himija rastitel'nogo syr'ja, 2013, no. 2, pp. 139-146. (in Russ.).

16. Botirov Je.H., Drenin A.A., Makarova A.V. Himija rastitel'nogo syr'ja. 2006, no. 1, pp. 45-48. (in Russ.).

17. Zajchikova S.G., Samylina I.A. Novozhilova T.I. Himiko-farmacevticheskij zhurnal, 2001, vol. 35, no. 5, pp. 36-38. (in Russ.).

18. Bashilov A.V. Izvestija nacional'noj akademii nauk Belorussii. Serija biologicheskih nauk. 2012, no. 1, pp. 119-123. (in Russ.).

19. Kitaeva M.V., Zubarev A.V., Spiridovich E.V., Reshetnikov V.N. Trudy BGU. Biohimija. 2011, vol. 6, no. 1, pp. 123-127. (in Russ.).

20. Kurkina A.V., Osipova A.A. Himija rastitel'nogo syr'ja, 2010, no. 2, pp. 117-121. (in Russ.).

21. Husainova A.I., Kurkina A.V. Izvestija Samarskogo nauchnogo centra Rossijskoj akademii nauk, 2013, vol. 15, no. 3(6), pp. 1984-1987. (in Russ.).

\footnotetext{
* Corresponding author.
} 
